\title{
Brachionus rotundiformis Tschugunoff, 1921 from the Brachionus plicatilis species complex (Rotifera: Monogononta): A new record from Galápagos Archipelago, Ecuador
}

\author{
Carlos López ; Miriam Steinitz-Kannan²; Georgia Stamou ${ }^{3,7}$; Evangelia Michaloudi, ; \\ Spiros Papakostas ${ }^{4}$; Diego Fontaneto ${ }^{5}$ \& Hendrik Segers ${ }^{6}$
}

${ }^{1}$ Universidad Técnica de Manabí (UTM), Facultad de Ciencias Veterinarias, Escuela de Acuicultura y Pesquería. Manabí. Ecuador. Escuela Superior Politecnica del Litoral (ESPOL), Facultad de Ciencias de la Vida, Centro del Agua y Desarrollo Sustentable. Guayaquil, Ecuador. Universidad del Zulia (LUZ), Facultad Experimental de Ciencias, Departamento de Biología. Maracaibo, Venezuela. ORCID: http://orcid.org/0000-0001-5267-7257. E-mail: cllopez@utm.edu.ec (corresponding author).

${ }^{2}$ Northern Kentucky University (NKU), Department of Biological Sciences. Highland Heights, Kentucky, United States. ORCID: http://orcid.org/0000-0002-6361-0186. E-mail: kannan@nku.edu.

${ }^{3}$ Aristotle University of Thessaloniki (AUTH), School of Biology, Department of Zoology. Thessaloniki, Greece.

${ }^{4}$ University of Turku (UTU), Department of Biology, Division of Genetics and Physiology. Turku, Finland. ORCID: http://orcid.org/0000-0002-5563-0048. E-mail: spiros.papakosta@utu.fi

${ }^{5}$ Water Research Institute (IRSA), National Research Council. Verbania. Pallanza, Italy. ORCID: http://orcid.org/0000-0002-5770-0353. E-mail: diego.fontaneto@cnr.it

${ }^{6}$ Royal Belgian Institute of Natural Sciences, Direction of Natural Environment. Brussels, Belgium. ORCID: http://orcid.org/0000-0001-5399-3657.E-mail: hsegers@naturalsciences.be

7 ORCID: http://orcid.org/0000-0002-0709-3698. E-mail: gstamouc@bio.auth.gr

${ }^{8}$ ORCID: http://orcid.org/0000-0001-8194-2865. E-mail: thioli@bio.auth.gr

\begin{abstract}
The presence of the rotifer species Brachionus rotundiformis from the B. plicatilis species complex in Lake Arcturo, a saline lake in the Genovesa Island of the Galápagos Islands, is here reported. This is the first record of the species for the rotifer fauna of Ecuador as well as of the species complex to the Galápagos Islands. This finding is consistent with the idea of high dispersion capacity, and of cosmopolitan distribution of this species complex. Because Genovesa Island is uninhabited, passive transport by wind currents and zoochory by migrant birds seem to emerge as the most plausible factors in this process of colonization. Integrative studies on the morphological variations, genetic, molecular, and ecological aspects are still required to further understand the process of dispersion and the ecology of this member of the B. plicatilis species complex in this remote and isolated locality, and the exact taxonomical position of the island's population to the other members of the complex.
\end{abstract}

Key-Words. Brachionidae; Geographical distribution; Neotropics; Rotifers; South America.

\section{INTRODUCTION}

Brachionus plicatilis Müller, 1786 is one of the best known monogonont rotifers. This taxon has been extensively studied, owing to its successful use in aquaculture (Lubzens, 1987; Lubzens et al., 2001) and ecotoxicology (Kostopoulou et al., 2012; Rico-Martínez et al., 2017; Won et al., 2017) and presently constitutes a model organism in ecological and evolutionary studies (Declerck \& Papakostas, 2017; Serra \& Fontaneto, 2017).

Traditionally, B. plicatilis has been considered a cosmopolitan morphologically variable taxon associated to saline waterbodies (Ahlstrom,
1940; Koste, 1978). However, detailed analyses on their morphology (Fu et al., 1991a), allozyme patterns (Fu et al., 1991b), temperature-driven fecundity patterns (Hirayama \& Rumengan, 1993), karyotype differences (Rumengan et al., 1991) as well as the outcome of assortative mating experiments (Fu et al., 1993; Gómez \& Serra, 1995; RicoMartínez \& Snell, 1995) contributed in the recognition that $B$. plicatilis is not a single species, but a species complex.

Initially, the complex was considered to consist of two different morphologically distinguishable morphotypes, namely 'S' (small) and 'L' (large), based on the average size difference of individu- 
als of comparable developmental sex and age. Segers (1995) formally recognized the two as belonging to different species-level taxa, and consequently re-established the names Brachionus rotundiformis Tschugunoff, 1921 and B. plicatilis sensu stricto (s.s.) for the S and L morphotypes, respectively.

Subsequently, more size-forms were recognized (Yúfera, 2001) and three clades that corresponded to three size groups were suggested, namely the Large (L), Small medium (SM) and Small small (SS) clades (Ciros-Pérez et al., 2001; Mills et al., 2017). The advent of low-cost DNA sequencing methodologies, and critically, the application of molecular-based species delimitation techniques (e.g., Fontaneto et al., 2015), allowed the recognition of more species at the B. plicatilis species complex. Currently, besides $B$. plicatilis S.S. and B. rotundiformis, the described species are Brachionus ibericus Ciros-Pérez, Gómez \& Serra, 2001 and Brachionus koreanus, Hwang, Dahms, Park \& Lee, 2013 as SM morphotypes, and Brachionus manjavacas Fontaneto, Giordani, Melone \& Serra, 2007 and Brachionus asplanchnoidis Charin, 1947 as L-morphotype (Ciros-Pérez et al., 2001; Fontaneto et al., 2007; Hwang et al., 2013; Michaloudi et al., 2017; Mills et al., 2017).

The actual number of species in the complex worldwide has been established to be at least fifteen (Mills et al., 2017; Serra \& Fontaneto, 2017). The recent overview by Mills et al. (2017) has confirmed the cosmopolitan distribution of each species thus refuting the suggestion that individual species may have narrower geographic distributions, but also noted gaps in the known distribution of the complex.
Studies on rotifer fauna of continental Ecuador are scarce and relatively recent (Koste \& Bötterg, 1989, 1992). After these seminal papers, only a small number of studies detailing on rotifers from inland water bodies of Ecuador has been published (De Cruz, 1998; Torres \& Palacios, 2007; Quimi, 2014; Valencia, 2015). Similarly, the rotifer fauna of the Galapagos Islands has been very little studied. Only three references are available, and none mentioned the B. plicatilis species complex (De Smet, 1989; Segers, 1991; López et al., 2018).

In this paper, the presence of the rotifer $B$. rotundiformis from the $B$. plicatilis species complex is reported in Lake Arcturo, a saline crater lake located on Genovesa Island, the Galápagos Archipelago, Ecuador. This is the first record of this taxon for Ecuador and the first record of the species complex to Galápagos Islands.

\section{MATERIAL AND METHODS}

\section{Sampled locality}

Analyzed material was collected at Lake Arcturo (WGS84 coordinates: $00^{\circ} 19^{\prime} 40^{\prime \prime} \mathrm{N}, 89^{\circ} 57^{\prime} 30^{\prime \prime} \mathrm{W}$ ) which sits at sea level on the center of Isla Genovesa, an uninhabited, $17 \mathrm{~km}^{2}$ island located in the northeastern Galápagos Archipelago (Fig. 1). The lake is circular with $500 \mathrm{~m}$ in diameter, $27.5 \mathrm{~m}$ deep at its maximum depth, and is surrounded by steep, $60 \mathrm{~m}$ crater walls (Fig. 2). A dense red mangrove (Rhizophora mangle Linnaeus, 1753) thicket
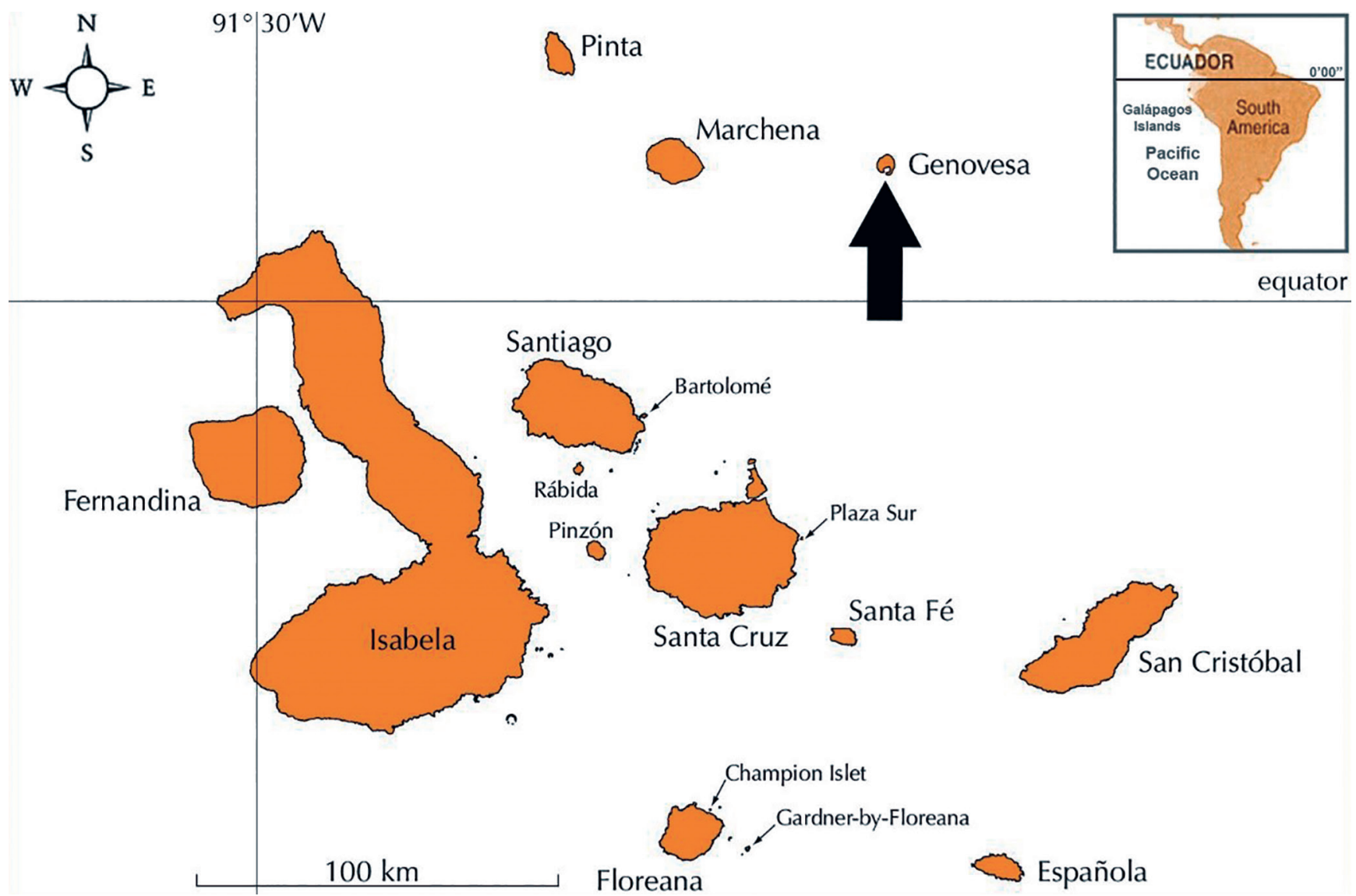

Figure 1. Map of the Galápagos Archipelago showing the location of the Genovesa Island and Lake Arcturo. 


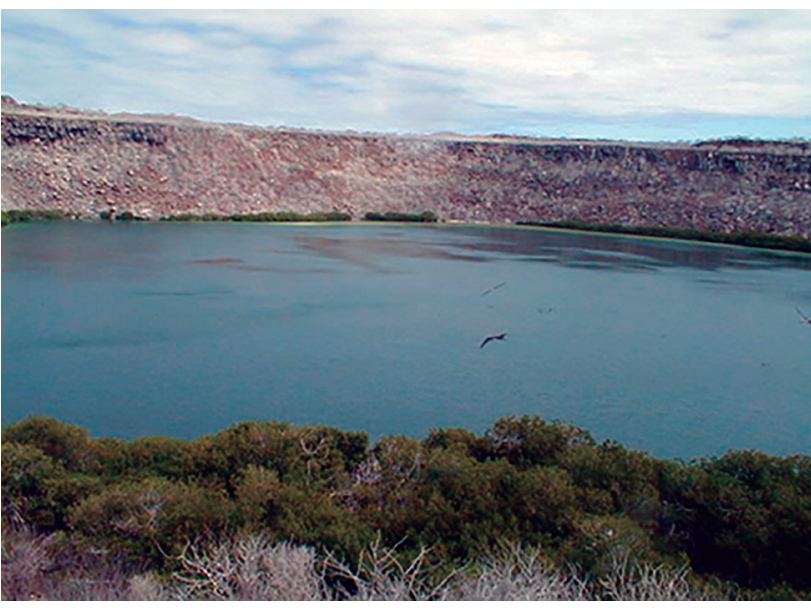

Figure 2. Photo of Lake Arcturo.

covers the lakeshore. The northeastern shore of the lake has a shallow-water beach area, whereas the southern part of the basin has much steeper bathymetry. Although the lake is connected to the ocean through many fissures in the island basalt a distinct seawater inlet is not obvious. Stable isotope values of water, as well as major cations and anions, indicate that the lake is hypersaline, with salinity roughly 1.5 times that of seawater (Conroy et al., 2014). The lake is frequented by large numbers of seabirds and is an outstanding example of guanotrophy. Primary production in the epilimnion is high, and the hypolimnion is usually anoxic. The lake is probably stratified during the entire year (Walker \& Likens, 1975; Bryhn, 2009). There appears to be no fish in the lake. The invertebrate fauna is dominated by corixid bugs and tanaid shrimps (Howmiller, 1969). More information on this lake is given in Conroy et al. $(2014,2015)$.

\section{Samples and examination of the material}

Samples for the present study were collected on September $9^{\text {th }}, 2004$, using a standard conical plankton net (mesh size $63 \mu \mathrm{m}$ ). They were fixed with $4 \%$ formalin solution and the individuals of the B. plicatilis complex were analyzed under a Leitz Laborlux $S$ optical microscope. Photographs for each of the 20 individuals were taken with an adjusted camera Canon Power shot A650 IS, and morphometric measurements were obtained using ImageJ (Abramoff et al., 2004). A total of 18 lorica dimensions were measured based on Fu et al. (1991a), Ciros-Pérez et al. (2001), Proios et al. (2014), and Michaloudi et al. (2017). Examined material is deposited in the rotifers collection of Dr. Evangelia Michaloudi in Department of Zoology, Aristotle University of Thessaloniki, Thessaloniki, Greece. Other voucher specimens were deposited in the collection of aquatic invertebrates of Dr. Miriam Steinitz-Kannan in Department of Biological Sciences, Northern Kentucky University, Highland Heights, Kentucky, U.S.A, and in the rotifer collection of Dr. Carlos López in Escuela de Acuicultura y Pesquería, Universidad Técnica de Manabí, Bahía de Caráquez, Ecuador.
Table 1. Summary statistics (minimum, maximum, mean and standard error, in $\mu \mathrm{m}$ ) for the selection of morphometric traits measured for the $B$. rotundiformis individuals from Lake Arcturo, Genovesa Island. Lorica measurements following Fu et al. (1991a); Ciros-Pérez et al. (2001); Proios et al. (2014); Michaloudi et al. (2017).

\begin{tabular}{ccccc}
\hline * Lorica measurements & Min & Max & Mean & St. error \\
\hline a & 130.83 & 199.81 & 164.29 & 17.08 \\
c & 107.44 & 152.52 & 123.92 & 14.63 \\
b & 64.08 & 103.11 & 84.70 & 10.77 \\
m & 39.90 & 73.96 & 57.01 & 8.52 \\
e & 18.89 & 30.89 & 23.65 & 4.03 \\
h & 6.73 & 20.64 & 14.43 & 3.79 \\
I & 8.97 & 19.56 & 14.29 & 3.65 \\
g & 5.31 & 12.42 & 10.03 & 2.19 \\
k & 17.02 & 24.68 & 20.58 & 2.08 \\
j & 20.38 & 29.31 & 24.44 & 2.97 \\
o & 18.60 & 27.67 & 23.36 & 2.92 \\
n & 8.71 & 26.12 & 14.52 & 4.68 \\
f & 14.61 & 28.15 & 21.88 & 3.59 \\
d & 0.00 & 26.90 & 15.33 & 7.43 \\
i & 60.92 & 100.46 & 84.16 & 11.13 \\
p & 10.59 & 30.43 & 22.51 & 6.03 \\
q & 15.25 & 25.37 & 20.14 & 3.07 \\
r & 12.375 & 23.64 & 15.94 & 2.73 \\
\hline
\end{tabular}

\section{RESULTS AND DISCUSSION}

Based on the morphometrical analysis as well as the morphology of the examined individuals (Fig. 3, Table 1), it is evident that the taxon found corresponds to the SS-type morphological group of the species complex. More specifically our specimens are characterized by the small lorica length $(131-200 \mu \mathrm{m})$ that falls within the range described by Ciros-Pérez et al. (2001) for B. rotundiformis, as well as the pattern of the anterodorsal spines with the second spine being shorter (g: 5-12 $\mu \mathrm{m}$ ) compared to the other two (h: 7-21 $\mu \mathrm{m}, \mathrm{j}: 20-29 \mu \mathrm{m}$ ) (Table 1). The anteroventral side also corresponds well with the $B$. rotundiformis morphology (Fig. 3). This feature has recently been proven to hold strong diagnostic features in Brachionus species (Michaloudi et al., 2017, 2018). Despite the clear morphological resemblance of our specimens with $B$. rotundiformis we should mention that Mills et al. (2017) phylogenetically recognized two clades in the SS group, namely clade SS1 corresponding to $B$. rotundiformis, and clade SS2 whose morphological identity is yet unknown.

The B. plicatilis species complex is considered cosmopolitan (Serra \& Fontaneto, 2017) and is found in brackish and estuarine habitats of continental Ecuador (De Cruz, 1998; Torres \& Palacios, 2007) and other regions of the Neotropics (Koste \& José de Paggi, 1982; José de Paggi \& Koste, 1995; Vásquez et al., 1998; Garraffoni \& Lourenço, 2012; Ferrando \& Claps, 2016). Particularly in the Neotropical zone, the species $B$. rotundiformis has been reported only from Mexico (Sarma et al., 2000), Brazil (Garraffoni \& Lourenço, 2012) and Argentina (Ferrando \& Claps, 2016). Of the two clades proposed by Mills et al. (2017) phylogenetically recognized in the SS group, the 


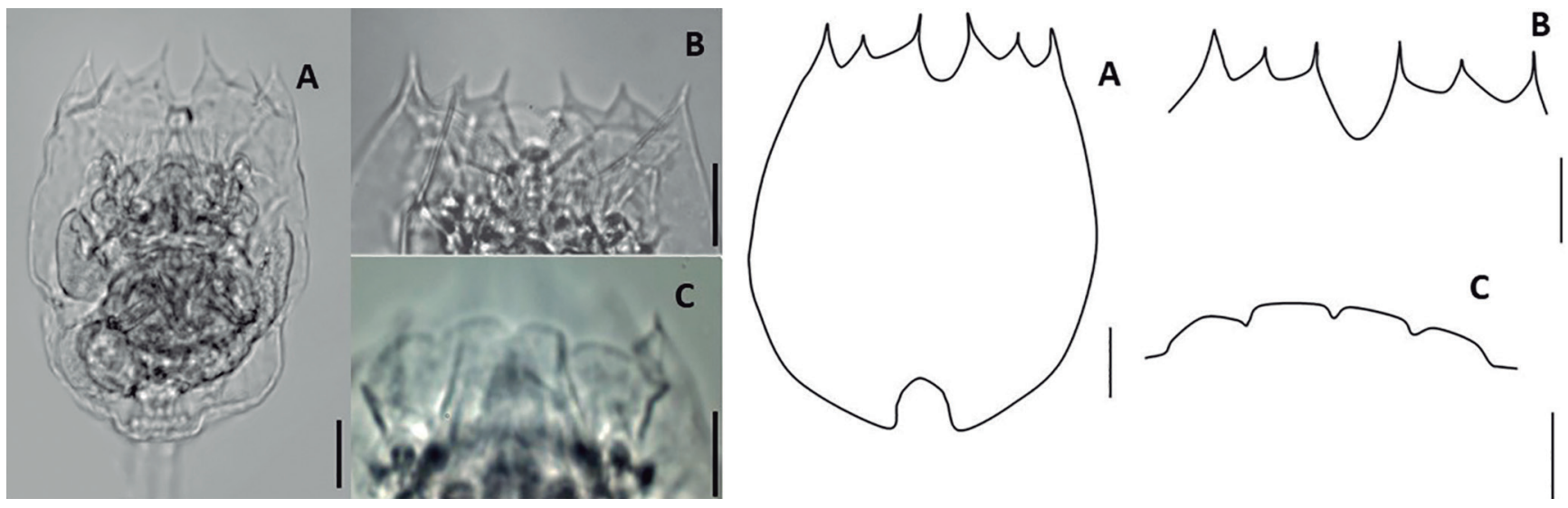

Figure 3. Brachionus rotundiformis microphotographs and drawings. (A) Dorsal view (B) anterodorsal margin; (C) anteroventral margin (Scale bars: $25 \mu \mathrm{m})$.

clade B. rotundiformis (SS1) is a widespread species found in all seven continents, while clade SS2 has only been recorded in two continents.

The presence of $B$. rotundiformis in Lake Arcturo in Genovesa Island is consistent with the great dispersal ability in this species complex (Serra \& Fontaneto, 2017). Among the mechanisms of dispersion of rotifers indicated by Segers \& De Smet (2008), passive transport by wind currents and zoochory by migrant birds emerge as most plausible factors in the process of colonization. In the Galápagos Archipelago, about 27 species of migrant birds are found (Windenfeld, 2006) and particularly Lake Arcturo is inhabited by large seabird populations (Howmiller, 1969). Since Genovesa Island is uninhabited, the effects of human activities are reduced to visiting tourists. However, the number of human visitors to the islands has increased exponentially in the last 30 years and may be associated with the recent colonization of Keratella cochlearis in San Cristóbal Island (López et al., 2018). Still in the case of Genovesa, we hypothesize that human activities are less important in the introduction of rotifers compared to the other inhabited islands. More studies are required to understand the process of dispersion of this complex species in Galápagos islands. Due to the remoteness and isolation of the studied locality, this record of $B$. rotundiformis is particularly important in relation to the processes of dispersion and speciation of the species complex.

\section{ACKNOWLEDGEMENTS}

Suggestions and criticisms of referees improved a first version of the manuscript. Thanks to staff of the Centro del Agua y Desarrollo Sustentable (CADS) of ESPOL for support in laboratory. Plankton collections on the Galápagos, including Lake Arcturo were funded by The US National Science Foundation, NOAA and National Geographic grants to MSK and her colleagues. We thank the Charles Darwin Research Station and the Galápagos National Park Foundation for providing logistic support including permits to study Lake Arcturo (Proyecto № PC 08-04). Special thanks for María Belén López for the help with the map.
Authors' contribution: MSK collection of samples; $\mathrm{CL}$ identified the material; EM, GW, HS confirmed identification, took the digital images, made drawings and made measurements; MSK, CL, EM, GW, SP, DF and HS wrote the text.

\section{REFERENCES}

Abramoff, M.; Magalhães, P. \& Ram, S. 2004. Image processing with ImageJ. Biophotonics International, 11: 36-42.

Ahlstrom, E.H. 1940. A revision of the rotatorian genera Brachionus and Platyias, with descriptions of one new species and two new varieties. Bulletin of the American Museum of Natural History, 77: 143-184.

Bryhn, A. 2009. A morphometrically based method for predicting water layer boundaries in meromictic lakes. Hydrobiologia, 636: 413-419. D0I

Ciros-Pérez, J.; Gómez, A. \& Serra, M. 2001. On the taxonomy of three sympatric sibling species of the Brachionus plicatilis (Rotifera) complex from Spain, with the description of $B$. ibericus $n$. sp. Journal of Plankton Research, 23: 1311-1328. D0I

Conroy, J.L.; Collins, A.F.; Overpeck, J.T.; Bush, M.B.; Cole, J.E. \& Anderson, D.J. 2015. A 400-year isotopic record of seabird response to eastern tropical Pacific productivity. Geography and Environment, 2: 137-147. D0I

Conroy, J.L.; Thompson, D.M.; Collins, A.; Overpeck, J.T.; Bush, M.B. \& Cole, J.E. 2014. Climate influences on water and sediment properties of Genovesa Crater Lake, Galápagos. Journal of Paleolimnology, 52: 331-347. D0I

De Cruz, M. 1998. Aporte al conocimiento del zooplancton de agua dulce y estuarina del Río Guayas, Guayaquil, Ecuador. Acta Oceanográfica del Pacifico, 9: 171-176.

De Smet, W. 1989. Rotifera uit de Galápagoseilanden. Natuurwetenschappelijk Tijdschrift, 69: 110-131.

Declerck, S. \& Papakostas, S. 2017. Monogonont rotifers as model systems for the study of micro-evolutionary adaptation and its eco-evolutionary implications. Hydrobiologia, 796: 131-144. DOI

Ferrando, N. \& Claps, M. 2016. A revised and updated checklist of Monogononta rotifers from Argentina. Check List, 12: 1-26.

Fontaneto, D.; Flot, J. \& Tang, C. 2015. Guidelines for DNA taxonomy, with a focus on the meiofauna. Marine Biodiversity, 45: 433-451.

Fontaneto, D.; Giordani, I.; Melone, G. \& Serra, M. 2007. Disentangling the morphological stasis in two rotifer species of the Brachionus plicatilis species complex. Hydrobiologia, 583: 297-307. D01

Fu, Y.; Hagiwara, A. \& Hirayama, K. 1993. Crossing between seven strains of the rotifer Brachionus plicatilis. Nippon Suisan Gakkaishi, 59: 2009-2016. Dol 
Fu, Y.; Hirayama, K. \& Natsukaki, Y. 1991a. Morphological differences between the two types of the rotifer Brachionus plicatilis 0.F. Muller. Journal of Experimental Marine Biology and Ecology, 151: 29-41. DOI

Fu, Y.; Hirayama, K. \& Natsukaki, Y. 1991b. Genetic divergence between S and $L$ type strains of the rotifer Brachionus plicatilis 0.F. Muller. Journal of Experimental Marine Biology and Ecology, 151: 43-46. D0I

Garraffoni, A.R.S. \& Lourenço, A.P. 2012. Synthesis of Brazilian Rotifera: an updated list of species. Check List, 8: 375-407. DOI

Gómez, A. \& Serra, M. 1995. Behavioral reproductive isolation among sympatric strains of Brachionus plicatilis Müller 1786: insights into the status of this taxonomic species. Hydrobiologia, 313:111-119. D0I

Hirayama, K. \& Rumengan, I. 1993. The fecundity patterns of $S$ and $L$ type rotifers of Brachionus plicatilis. Hydrobiologia, 255/256: 153-157. D01

Howmiller, R. 1969 Studies on some inland waters of the Galapagos. Ecology, 50: 73-80. DOI

Hwang, D.; Dahms, H.; Park, H. \& Lee, J. 2013. A new intertidal Brachionus and intrageneric phylogenetic relationships among Brachionus as revealed by allometry and C01-ITS1 gene analysis. Zoological Studies, 52: 1-10. $\underline{\mathrm{DOl}}$

José de Paggi, S. \& Koste, W. 1995 Additions to the checklist of Rotifers of the superorder Monogononta recorded from Neotropis. International Revue der Gesamten Hydrobiologie und Hydrographie, 80: 133-140. D0I

Koste, W. 1978. Rotatoria. Die Rädertiere Mitteleuropas Ein Bestimmungswerk, begründet von Max Voigt Überordnung Monogononta. Stuttgart, Gebrüder Borntraeger.

Koste, W. \& Böttger, K. 1989. Rotatorien aus Gewässer Ecuadors. Amazoniana, 10(4): 407-438.

Koste, W. \& Böttger, K. 1992. Rotatorien aus Gewässer Ecuadors II. Amazoniana, 12(2): 263-303.

Koste, W. \& José de Paggi, S. 1982. Rotifera of the superorder Monogononta recorded from Neotropis. Gewässer und Abwässer, 68/69: 71-102.

Kostopoulou, V.; Carmona, M. \& Divanach, P. 2012. The rotifer Brachionus plicatilis: an emerging bio-tool for numerous applications. Journal of Biological Research-Thessaloniki, 17: 97-112.

López, C.; Steinitz-Kannan, M. \& Segers, H. 2018. Occurrence of the rotifer Keratella cochlearis (Gosse, 1851) in San Cristóbal Island, Galápagos Archipelago, Ecuador. Check List, 14(5): 811-815. D0I

Lubzens, E. 1987. Raising rotifer for use in aquaculture. Hydrobiologia, 147: 245-255. DOI

Lubzens, E.; Zamora, 0. \& Barr, T. 2001. Biotechnology and aquaculture of rotifer. Hydrobiologia, 446/447: 337-353.

Michaloudi, E.; Mills, S.; Papakostas, S.; Stelzer, C.-P.; Triantafyllidis, A.; Kappas, I.; Vasileiadou, K. \& Proios, K. 2017. Morphological and taxonomic demarcation of Brachionus asplanchnoidis Charin within the Brachionus plicatilis cryptic species complex (Rotifera, Monogononta). Hydrobiologia, 796(1): $19-37$.

Michaloudi, E.; Papakostas, S.; Stamou, G.; Neděla, V.; Tihlařiková, E.; Zhang, W. \& Declerck, S.A.J. 2018. Reverse taxonomy applied to the Brachionus calyciflorus cryptic species complex: morphometric analysis confirms species delimitations revealed by molecular phylogenetic analysis and allows the (re)description of four species. Plos One, 13: e0203168. DOI

Mills, S.; Alcántara-Rodríguez, A.; Ciros-Pérez, J.; Gómez, A.; Hagiwara, A.; Hinson, K.; Galindo, C.; Jersabek, D.; Malekzadeh-Viayeh, R.; Leasi, F.; Lee, J.; Welch, M.; Papakostas, S.; Riss, S.; Segers, H.; Serra, M.; Shiel, R.; Smolak, R.; Snell, T.; Stelzer, C.-P; Tang, C.; Wallace, R.; Fontaneto, D. \& Walsh, E. 2017. Fifteen species in one: deciphering the Brachionus plicatilis species complex (Rotifera, Monogononta) through DNA taxonomy. Hydrobiologia, 796: 39-58. DOI

Proios, K.; Michaloudi, E.; Papakostas, S.; Kappas, I.; Vasileiadou, K. \& Abatzopoulos, T. 2014. Updating the description and taxonomic status of Brachionus sessilis Varga, 1951 (Rotifera: Brachionidae) based on detailed morphological analysis and molecular data. Zootaxa, 3873: 345-370. DOI

Quimi, G. 2014. Composición y abundancia del zooplancton en la Represa San Vicente, Comuna Las Balsas, durante junio-noviembre del 2013, Santa Elena - Ecuador. (Undergraduate dissertation). Universidad Estatal península de Santa Elena. Santa Elena. http://repositorio.upse.edu.ec/ handle/46000/1874

Rico-Martínez, R. \& Snell, T. 1995. Mating behavior and mate recognition pheromone blocking of male receptors in Brachionus plicatilis Müller (Rotifera). Hydrobiologia, 313/314: 105-110. D01

Rico-Martínez, R.; Arzate-Cárdenas, M.; Alvarado-Flores, J.; Pérez-Legaspi, A. \& Santos-Medrano, E. 2017. Rotifers as model for ecotoxicology and genotoxicology. In: Larramendy, M. (Ed.). Ecotoxicology and Genotoxicology: nontraditional aquatic models. United Kingdom, Royal Society of Chemistry. cap. 3, p. 48-69.

Rumengan, l.; Kayano, H. \& Hirayama, K. 1991. Karyotypes of S and L type rotifers Brachionus plicatilis 0.F. Muller. Journal of Experimental Marine Biology and Ecology, 154(2): 171-176. DOI

Sarma, S.; Nandini, S.; Ramírez, P. \& Cotés, J. 2000. New records of brackish water Rotifera and cladocera from México. Hidrobiologica, 10: 121-124.

Segers, H. 1991. Contribution to the knowledge of the rotifer fauna of the Galápagos islands. Biologisch Jaarboek (Dodonaea), 58: 113-119.

Segers, H. 1995. Nomenclatural consequences of some recent studies on Brachionus plicatilis (Rotifera, Brachionidae). Hydrobiologia, 313: 121-122. D0I

Segers, H. \& De Smet, W. 2008. Diversity and endemism in Rotifera: a review, and Keratella Bory de St Vincent. Biodiversity and Conservation, 17: 303-316. DOI

Serra, M. \& Fontaneto, D. 2017. Speciation in the Brachionus plicatilis Species Complex. In: A. Hagiwara, A.\& Yoshinaga, T. (Eds.). Rotifers: Aquaculture, Ecology, Gerontology and Ecotoxicology. Singapore, Springer. p. 15-32.

Torres, G. \& Palacios, C. 2007. Calidad Ambiental del Bloom algal en el área urbana del Estero Salado (Ciudad de Guayaquil) en junio 2005. Acta Oceanográfica del Pacífico, 14: 115-124.

Valencia, N. 2015. Diversidad de rotíferos en el área nacional de recreación "Parque Lago", Embalse Chongón. (Undegraduate Dissertation). Universidad de Guayaquil. http://repositorio.ug.edu.ec/handle/ redug/ $/ 2123$

Vásquez, E.; Pardo, M.; Zoppi de Roa, E. \& López, C. 1998. Rotifer fauna from Venezuela. Amazoniana, 15: 11-24.

Walker, K. \& Likens, G. 1975. Meromixis and a reconsidered typology of lake circulation patterns. Verhandlungen Internationale Vereinigung für Theoretische und Angewandte Limnologie, 19: 442-458.

Windenfeld, D. 2006. Aves, The Galapagos Islands, Ecuador. Check List, 2: 1-27. DOI

Won, E.; Han, J.; Kim, D.; Dahms, H. \& Lee, J. 2017. Rotifers in Ecotoxicology. In: Hagiwara, A. \& Yoshinga, T. (Eds.). Rotifers: Aquaculture, Ecology, Gerontology and Ecotoxicology. Singapore, Springer. p. 149-177.

Yúfera, M. 2001. Studies on Brachionus (Rotifera): an example of interaction between fundamental and applied research. Hydrobiologia, 446/447: 383-392. D01 